\title{
EphrinBs Regulate D-Serine Synthesis and Release in Astrocytes
}

\author{
Zhiye Zhuang, ${ }^{1}$ Bing Yang, ${ }^{1}$ Michelle H. Theus, ${ }^{1}$ Justin T. Sick, ${ }^{1}$ John R. Bethea, ${ }^{1}$ Thomas J. Sick, ${ }^{2}$ and Daniel J. Liebl ${ }^{1}$ \\ ${ }^{1}$ The Miami Project to Cure Paralysis and Department of Neurosurgery, and ${ }^{2}$ Department of Neurology, University of Miami Miller School of Medicine, \\ Miami, Florida 33136
}

There is growing evidence that astrocytes play critical roles in neuron-glial interactions at the synapse. Astrocytes are believed to regulate presynaptic and postsynaptic structures and functions, in part, by the release of gliotransmitters such as glutamate, ATP, and D-serine; however, little is known of how neurons and astrocytes communicate to regulate these processes. Here, we investigated a family of transmembrane proteins called ephrinBs and Eph receptors that are expressed in the synapse and are known to regulate synaptic transmission and plasticity. In addition to their presence on CA1 hippocampal neurons, we determined that ephrins and Eph receptors are also expressed on hippocampal astrocytes. Stimulation of hippocampal astrocytes with soluble ephrinB3, known to be expressed on CA1 postsynaptic dendrites, enhanced D-serine synthesis and release in culture. Conversely, ephrinB3 had no effect on D-serine release from astrocytes deficient in EphB3 and EphA4, which are the primary receptors for ephrinB3. Eph receptors mediate this response through interactions with PICK1 (protein interacting with C-kinase) and by dephosphorylating protein kinase $\mathrm{C} \alpha$ to activate the conversion of $\mathrm{L}$-serine to $\mathrm{D}$-serine by serine racemase. These findings are supported in vivo, where reduced D-serine levels and synaptic transmissions are observed in the absence of EphB3 and EphA4. These data support a role for ephrins and Eph receptors in regulating astrocyte gliotransmitters, which may have important implications on synaptic transmission and plasticity.

\section{Introduction}

Astrocytes are a critical third element in synaptic transmission that are assumed to be the electrically silent cohabitant of the CNS (Araque et al., 1999). Anatomical observations show that astrocytic processes enwrap up to $60 \%$ of the neuronal synaptic structure (Ventura and Harris, 1999). Despite this physical intimacy, astrocytes have been thought to function principally in cellular housekeeping, and structural and metabolic support. There is now a growing body of evidence for mutual communication between neurons and glia (Haydon, 2001; Fields and Stevens-Graham, 2002; Volterra and Meldolesi, 2005). Astrocytes detect changes in the activity of their adjacent neurons through ion channels, receptors and transporters expressed on their surface and, in turn, respond by releasing a variety of neuroactive materials known as gliotransmitters. Gliotransmitters that mediate astrocyte to neuron signaling include glutamate (Angulo et al., 2004; Fellin and Carmignoto, 2004), D-serine and ATP (Mothet et al., 2000; Newman, 2003; Zhang et al., 2003; Gordon et al., 2005). Most D-serine is synthesized in astrocytes by serine racemase (SR), which directly converts L-serine to D-serine

Received Jan. 28, 2010; revised Sept. 30, 2010; accepted Oct. 4, 2010.

This work was supported by the Miami Project to Cure Paralysis (D.J.L.), and National Institutes of HealthNational Institute of Neurological Disorders and Stroke Grants NS049545 and NS30291 (D.J.L.). We thank Drs. Mark Henkemeyer and Patrick Charnay for their generous gift of the mutant mice, and Dr. Jerome Ricard for critical review of this manuscript.

Correspondence should be addressed to Dr. Daniel I Liebl, Associate Professor of Neuroscience, Director, Neuroscience Graduate Program, The Miami Project to Cure Paralysis, The University of Miami Miller School of Medicine, 1095 NW 14th Terrace, R-48, Miami, FL 33136. E-mail: dliebl@miami.edu.

D0I:10.1523/JNEUROSCI.0481-10.2010

Copyright $\odot 2010$ the authors $\quad$ 0270-6474/10/3016015-10\$15.00/0
(Wolosker et al., 1999a; Stevens et al., 2003) and is released after glutamate receptor stimulation through a calcium- and SNAREdependent exocytotic pathway (Mothet et al., 2005). D-Serine serves as an endogenous coagonist at strychnine-insensitive glycine sites of NMDA receptors (Schell et al., 1997; Stevens et al., 2003; Yang et al., 2003; Shleper et al., 2005; Panatier et al., 2006b), and is important in regulating long-term potentiation (Henneberger et al., 2010). SR, a bifunctional enzyme, also produces pyruvate in cultured cells through the $\alpha, \beta$-elimination of water from L- and D-serine (Foltyn et al., 2005). In the mitochondria, pyruvate decarboxylation leads to the production of diverse amino acids, such as glutamate, glutamine and glycine, and ATP to modulate synaptic transmission (Araque et al., 1999; Cotrina et al., 2000; Halassa et al., 2007; Jourdain et al., 2007).

Erythropoietin-producing hepatocellular carcinoma (Eph) receptors form the largest known family of receptor tyrosine kinases. Currently, 16 genes (EphA1-10, EphB1-6) have been identified in vertebrates, and most Ephs are known to have promiscuous interactions with multiple ephrin ligands. In the CNS, ephrin ligands and their cognate Eph receptors guide axons during neuronal development and regulate synapse formation and neural plasticity in the adult (Klein, 2009). Dendritic ephrinB3 promotes both dendritic spine and synapse formation (Henkemeyer et al., 2003; Aoto et al., 2007), and has high affinity interactions with both EphB3 and EphA4 receptors (Pasquale, 2008). Dendritic ephrinB3/EphA4 signaling also prevents growth cone extension in motor circuit formation via $\alpha$-chimerin-induced inactivation of Rac (Iwasato et al., 2007). Two independent lines of ephrinB3-null mice have defective CA3-CA1 LTP (Grunwald et al., 2004; Rodenas- 
Ruano et al., 2006). There is also clear evidence that Ephs mediate dendritic spine, synapse formation and synaptic plasticity, however, previous studies have not examined the effects of ephrins on hippocampal astrocytes. Here, we show that $\mathrm{B}$-class ephrins increase D-serine synthesis and release from hippocampal astrocytes, and ephrinB3 acts directly through EphB3/EphA4 receptors to modulate protein interacting with C-kinase (PICK1), protein kinase $\mathrm{C} \alpha(\mathrm{PKC} \alpha)$, and serine racemase activity in astrocytes that ultimately play a role in synaptic transmission.

\section{Materials and Methods}

Transgenic mice, breeding, and genotyping. EphB3 knock-out $\left({ }^{\mathrm{KO}}\right)$ and EphA4 ${ }^{K O} \mathrm{CD} 1$ mutant mice and genotyping methods have been described previously (Gale et al., 1996; Henkemeyer et al., 1996; Helmbacher et al., 2000). EphB3/EphA4 double knock-out (EphB3 $\left.{ }^{K O} / E p h A 4^{K O}\right)$ mice were generated through cross breeding of individual knock-out mice. Procedures related to animal use and care were approved by the University of Miami Animal Use and Care Committee.

Primary cultures of neonatal mouse astrocytes. Primary cultures of astrocytes were prepared from 1- to 3-d-old CD1 mouse pups as described previously (Neary et al., 1994). In brief, forebrains were removed from skulls and placed in cold HBSS (Invitrogen) with 10 mM HEPES. After careful dissection to remove meninges, cortices were minced, dissociated by trituration and vortexing, passed through sterile nylon sieves, and then plated in 24-well plates on poly-D-lysine-coated glass coverslips for immunocytochemistry, in 6-well plates for reverse transcription (RT)PCR and Western blot, in 12-well plates for measurement of D-serine. Cells were seeded at a density of 100,000 cells $/ \mathrm{ml}$. Culture volume was 2 $\mathrm{ml}$ per well in 6-well plates, $1 \mathrm{ml}$ per well in 12 -well plate, $0.5 \mathrm{ml}$ per well in 24 -well plates. The cultures were incubated at $37^{\circ} \mathrm{C}$ in a watersaturated atmosphere containing $5 \% \mathrm{CO}_{2} / 95 \%$ air and maintained in DMEM (Invitrogen) supplemented with 15\% FBS (Invitrogen) for the first week and 10\% FBS for the rest of the growth period. Astrocytes normally reached the stage of confluence 11-14 d after plating. Experiments were performed in triplicate using different batches of 3- to 6-week-old cell cultures. This procedure yielded cultures that were $>95 \%$ immunoreactive for glial fibrillary acidic protein.

Immunocytochemistry and imaging. The immunostaining was performed as described previously (Zhuang et al., 2006). Briefly, brain tissue sections and astrocyte cultures were fixed by $4 \%$ PFA in PBS for $30 \mathrm{~min}$, permeabilized in $0.3 \%$ Triton $\mathrm{X}-100$ for $1 \mathrm{~h}$ at room temperature, and blocked in 5\% normal goat serum (Jackson ImmunoResearch) and 5\% donkey normal serum (Jackson ImmunoResearch) for $20 \mathrm{~min}$. Primary antibodies specific for EphB1-3 (recognizes EphB1, EphB2 and EphB3) (kind gift from Dr. Zavin Kaprielian, Albert Einstein College of Medicine, Bronx, NY) (Jevince et al., 2006), EphB3 (Abcam Inc.), EphA4 (R\&D Systems), ephrinB1, ephrinB2, ephrinB3, and serine racemase (Santa Cruz Biotechnology), glial fibrillary acidic protein (GFAP) (Dako), OX42 (Abcam Inc.), $\beta$-tubulin III (Covance), and APC (Calbiochem) were diluted in PBS containing 5\% BSA/0.1\% Triton X-100 and allowed to incubate with sections and cell cultures overnight at $4^{\circ} \mathrm{C}$. Cultures were washed three times for $5 \mathrm{~min}$ each in PBS, then incubated with Alexa Fluor 488 and/or Alexa Fluor 594-conjugated second antibodies (Invitrogen) for $1 \mathrm{~h}$ at room temperature. Cultures were washed again in PBS and coverslipped using Gel/Mount anti-fading mounting media (Biomeda). Images were acquired using an inverted microscope (Axiovert 200M, Zeiss). Gain and exposure levels were set for control cultures and kept constant for all other cultures within an experiment.

Generation of ephrinB1 and ephrinB3 protein fragment. EphrinB1 extracellular domain: the gene fragment coding for the amino acids 26-236 of mouse ephrinB1 was PCR amplified and cloned between the NcoI and EcoRI restriction sites of the pET32a vector (Novagen) using the forward primer: 5' -catcccatggatacgccgttggccaagaac, and the reverse primer: $5^{\prime}$ ggcgaattctcacttggagttgaagaagctgtc. EphrinB3 extracellular domain: the gene fragment coding for the amino acids $28-227$ of mouse ephrinB3 was PCR amplified and cloned between the NcoI and EcoRI restriction sites of the pET32a vector (Novagen) using the forward primer:
5 '-catgccatggaactcagcctggagcctg and the reverse primer: 5'-ggcgaattctcacactgcgggcatgctg. The protein was expressed in E. coli AD494 (DE3) pLysS strain (Novagen). Culture were grown at $37^{\circ} \mathrm{C}$ with shaking until an $\mathrm{OD}_{600}=0.6$, and protein expression was induced with $1 \mathrm{~mm}$ IPTG for $16 \mathrm{~h}$ at $20^{\circ} \mathrm{C}$. The cells were harvested and lysed, followed by precipitation of the nucleic acids from the crude extract. The supernatant was used to perform ammonium sulfate (AMS) precipitation. The AMS pellet was resuspended in buffer A ( $20 \mathrm{~mm}$ Tris $\mathrm{HCl}, \mathrm{pH} 8.0,300$ mм NaCl, 10 mм imidazole, 10\% v/v glycerol) for immobilized metal ion affinity chromatography, and passed through a nickel column (PorosMC, GE Healthcare) over a 10-500 mm imidazole gradient. The fractions from the nickel column containing the protein were collected and ran on an anion exchange column (MonoQ HR 10/10, GE Healthcare). The eluted protein was further ran on a sizeexclusion column (Superdex200, GE Healthcare) in a buffer containing $150 \mathrm{~mm} \mathrm{NaCl}, 20 \mathrm{~mm}$ Tris-Cl, pH 7.5, 10\% glycerol, 1 mм EDTA, and $1 \mathrm{~mm}$ DTT. The protein was eluted in the void volume as a soluble aggregate. The purified proteins were tested for their ability to induce Eph phosphorylation in HEK 293 cells.

D-Serine measurements. D-Serine was measured by a chemiluminescent assay as described previously (Wolosker et al., 1999a). Astrocyte cultures were treated with inhibitors/ephrinB1 protein fragment or ephrinB3 protein fragment for $5 \mathrm{~min}, 15 \mathrm{~min}$ or $30 \mathrm{~min}$ and the media were collected for D-serine measurement. A $10 \mu \mathrm{l}$ sample was mixed with $100 \mu \mathrm{l}$ of medium containing $100 \mathrm{~mm}$ Tris- $\mathrm{HCl}, \mathrm{pH} 8.8,20 \mathrm{U} / \mathrm{ml}$ peroxidase, and $8 \mu \mathrm{M}$ luminol. After a $15 \mathrm{~min}$ delay to decrease the background signal of luminol, $10 \mu \mathrm{l}$ of D-amino acid oxidase (DAAO) $(75 \mathrm{U} / \mathrm{ml})$ were added. Chemiluminescence kinetics was recorded for $4 \mathrm{~min}$ at room temperature by using a Wallac 1420 multilabel counter (PerkinElmer). The concentration of D-serine in each sample was compared with a standard curve. The linear range is 50 1000 pmol of D-serine in the sample and the detection limit is $30 \mathrm{pmol}$. For intracellular D-serine measurement, 5\% trichloroacetic acid (TCA) was used to treat cells, and the precipitated proteins were removed by centrifugation. The supernatant was extracted two times using water-saturated diethyl ether to remove TCA. D-Serine was measured following the same steps as described above.

$R N A$ extraction and reverse transcription-PCR. Total RNA was extracted from cultured astrocytes using the TRIzol reagent (Invitrogen) following manufacturer's protocol and quantified by spectrophotometry. Two-step RT-PCR was performed using the ImProm-II Reverse Transcription System and GoTaq Flexi DNA Polymerase (Promega) according to supplier's protocol. The following primers were used: ephrinB1, forward: 5' caccatcaagttccaagat- $3^{\prime}$, reverse: $5^{\prime}$-cttctctcctggttcacag- $3^{\prime}$; ephrinB2, forward: $5^{\prime}$-tggaagtactgttggggact, reverse: $3^{\prime}$-tcacatcttggtctggtctg; ephrinB3, forward: $5^{\prime}$-gggaccggctagatctactt- $3^{\prime}$, reverse: $5^{\prime}$-ggctgtattcctggaacttg- $3^{\prime}$; $E p h B 1$, forward: $5^{\prime}$-atccggaacccagctagtctcaag- $3^{\prime}$, reverse: $5^{\prime}$-ggtggtaaaggccgtgaagtctg- $3^{\prime} ; E p h B 2$, forward: $5^{\prime}$-atccggaacccagctagtctcaag- $3^{\prime}$, reverse: $5^{\prime}$-ggtgtgtaatgtgcgtgagt- $3^{\prime} ; E p h B 3$, forward: $5^{\prime}$-ggtgtgtaatgtgcgtgagt- $3^{\prime}$, reverse: $5^{\prime}$ tggtgtccactttcacgtag- $3^{\prime} ; \quad$ EphA4, forward: $5^{\prime}$-aggaagtgagcattatggatga- $3^{\prime}$, reverse: $5^{\prime}$-tgctcctcgtgcccagcgtt-3'. The PCR products were loaded on $1 \%$ agarose gel, and were visualized with ethidium bromide. The reverse transcriptase was omitted in the negative control reaction and cDNA generated from mouse neonatal brain RNA were used in the positive control reaction. Both controls were applied in each running.

siRNA transfection. Two small interfering PICK1 siRNA (Prkcabp) were used, PICK1-1 (catalog \#J-048339-05-0005) and PICK1-2 (catalog \#J-048339-06-0005), to demonstrate specificity, as well as PSD95 (Dlgh4) siRNA (catalog \#J-040099-05-0005) and scrambled nontargeting siRNA (catalog \#D-001810-01-05) (Thermo Scientific Dharmacon RNAi Technologies). Upon confluence, primary mouse hippocampal astrocytes were plated in 6-well plates or 12-well plates at a density of 10,000 cells/ $\mathrm{ml}$. The loaded volume of each well is $1 \mathrm{ml}$ for 12 well plates and $2 \mathrm{ml}$ for 6-well plates. One day later, cells were transfected with siRNA at 5, 25 and $50 \mathrm{~nm}$ using HyPerfect transfect reagent (Qiagen) according to manufacturer's instructions. Seventy-two hours after transfection, cultures were treated with $0.1 \mu \mathrm{g} / \mathrm{ml}$ ephrinB3. Then media were collected for the analysis of D-serine levels and cells were used for determining gene knockdown efficiency using Western blot analysis. 
Electrophysiology. Long-term potentiation and paired pulse facilitation were examined in hippocampal slices harvested from either wild-type or $E p h B 3^{K O} / E p h A 4^{K O}$ mice. Animals were anesthetized with isoflurane, decapitated, the brain was removed and the hippocampus was dissected free and placed in chilled high sucrose sectioning medium containing the following (in mM): 100 sucrose, $60 \mathrm{NaCl}, 3 \mathrm{KCl}, 1.25 \mathrm{NaH}_{2} \mathrm{PO}_{4}, 28$ $\mathrm{NaHCO}_{3}, 0.5 \mathrm{CaCl}_{2}, 7 \mathrm{MgCl}_{2}, 0.6$ ascorbic acid, and 5 glucose. The hippocampus was mounted on a block of agarose and $350 \mu \mathrm{m}$ slices were cut with a Leica VT1000 vibratome maintained at $6^{\circ} \mathrm{C}$. Slices were then placed for a minimum of $1 \mathrm{~h}$ in a holding chamber containing artificial CSF (ACSF) containing the following (in $\mathrm{mM}$ ): $125 \mathrm{NaCl}, 2.5 \mathrm{KCl}, 1.25$ $\mathrm{NaH}_{2} \mathrm{PO}_{4}, 25 \mathrm{NaHCO}_{3}, 2 \mathrm{CaCl}_{2}, 1 \mathrm{MgCl}_{2}$, and 25 glucose. Slices were transferred to an interface-type recording chamber maintained at $35^{\circ} \mathrm{C}$. Bipolar stimulation electrodes were placed in the Schaffer collaterals and a glass recording micropipette was placed nearby in the stratum radiatum of subfield CA1. Electrical monopolar pulses were delivered from a Grass S48 stimulator at an intensity sufficient to elicit field EPSPs at halfmaximum amplitude. Field potentials were recorded using an Axopatch 2B amplifier, Digidata analog-to-digital converter, and Clampex 8.0 software. A strict software-controlled protocol was used which recorded 30 min of baseline data at a stimulation rate of $1 / \mathrm{min}$, a paired-pulse facilitation sequence in which stimulation pulse pairs were delivered at intervals of $20,50,100,200,400$, and $600 \mathrm{~ms}$, theta burst stimulation consisting of 2 consecutive $100 \mathrm{~Hz}, 20$ pulse trains delivered at an interval of $20 \mathrm{~s}$, and a $2 \mathrm{~h}$ post-tetanus recording period. EPSP amplitude and the initial EPSP slope were measured off-line. Post-tetanus data were analyzed using a repeated measure 2-way ANOVA.

Generation of lentiviruses expressing wild-type or mutant serine racemase with $V 5$ tag. The mouse serine racemase (SR) gene was PCR amplified from pCMV-SPORT5 vector (ATCC) and cloned between the BamHI and XhoI restriction sites of the pcDNA3.1/V5-His A vector (Invitrogen) using the forward primer: $5^{\prime}$-tttggatccgccaccatgtgtgctcagtactgc, and the reverse primer: $5^{\prime}$-tttctcgagaacagaaaccgtctggtaagg. The SR-V5 gene was then amplified from pcDNA3.1/V5-His A and cloned between the BamHI and SalI restriction sites of the pRRLsinPPT.CMV.MCS.Wpre vector (Invitrogen) using the forward primer: $5^{\prime}$-ctcggatccgccaccatgtgtgc, and the reverse primer: $5^{\prime}$-tttgtcgactcacgtagaatcgagaccgaggagag. The inactive K56G mutant SR (Wolosker et al., 1999b) was made using the GeneTailor site-directed mutagenesis system (Invitrogen). The forward primer: $5^{\prime}$-cagaaaactgggtcttttgggattcgaggtg, and the reverse primer: $5^{\prime}$-aaaagacccagttttctggaagagctcaca were used. Lentiviruses were generated by the Viral Core Laboratory at the Miami Project to Cure Paralysis, University of Miami Miller School of Medicine. Briefly, $24 \mathrm{~h}$ before transfection HEK 293T cells were plated in a T-150 flasks (using $20 \mathrm{ml}$ of high glucose DMEM plus $10 \%$ FBS) so the cells can reach $90 \%$ confluency at the day of transfection. For each flask, $1 \mathrm{ml}$ Opti-MEM I Reduced Serum Medium was mixed with $12.2 \mu \mathrm{g}$ of Transfer vector, $6.1 \mu \mathrm{g}$ of pMDL (Gag/Pol), $3.1 \mu \mathrm{g}$ of pREV, $3.7 \mu \mathrm{g}$ of pVSVG (vesicular stomatitis virus glycoprotein), gently mixed and incubated for $5 \mathrm{~min}$. After the $5 \mathrm{~min}$ incubation, DNA was combined with diluted Lipofectamine 2000, mixed gently and incubated for $20 \mathrm{~min}$ at room temperature, then overnight at $37^{\circ} \mathrm{C}$ in a $\mathrm{CO}_{2}$ incubator. The medium was removed and $30 \mathrm{ml}$ of fresh medium was added. After $40 \mathrm{~h}$ incubation, the supernatant was harvested and centrifuged at $500 \times g$ for $5 \mathrm{~min}$ at $4^{\circ} \mathrm{C}$, followed by filtration using on $0.45 \mu \mathrm{m}$ pore PVDF (polyvinylidene fluoride) Durapore filter (Millipore). The supernatant was then ultracentrifuged at 21,000 rpm for $2.3 \mathrm{~h}$ at $4^{\circ} \mathrm{C}$ in a SW-28 rotor (Beckman). The virus pellets were resuspended in PBS/1\% BSA. The viral titer was determined by p24 ELISA assay (PerkinElmer).

Western blot assays. Cultured astrocytes were homogenized in buffer containing the following (in $\mathrm{mm}$ ): 20 Tris- $\mathrm{HCl}, \mathrm{pH} 7.4,150 \mathrm{NaCl}, 1$ EDTA, 1 EGTA, 1\% Triton X-100, 1 PMSF, and a mixture of proteinase and phosphatase inhibitors (Sigma) (Zhuang et al., 2006). Protein samples were separated on $4-15 \%$ SDS polyacrylamide gels and transferred to PVDF filters. The blots were blocked with 5\% milk in PBS with $0.1 \%$ Tween 20 for $1 \mathrm{~h}$ at room temperature and incubated overnight at $4^{\circ} \mathrm{C}$ with primary antibodies. The blots were then incubated for $1 \mathrm{~h}$ at room temperature with HRP-conjugated secondary antibodies (Jackson ImmunoResearch) and bands were visualized using SuperSignal substrate
(Pierce). The following primary antibodies were used: anti-serine racemase (Santa Cruz Biotechnology), anti-PKC $\alpha$, anti-phospho-PKC $\alpha$ (Millipore), anti-PICK1 (Affinity BioReagents), and anti- $\beta$-actin (Sigma). Density analysis was performed using UN-SCAN-IT, standardized to $\beta$-actin, and a oneway ANOVA was used for statistical analysis.

Coimmunoprecipitation. Protein samples were immunoprecipitated with an anti-SR monoclonal antibody (BD Biosciences) overnight at $4^{\circ} \mathrm{C}$. Protein G Plus-Agarose (Calbiochem) was added into the mixture for $1 \mathrm{~h}$ at $4^{\circ} \mathrm{C}$. Bound proteins and total lysate were analyzed by SDS-PAGE followed by Western blot with anti-PICK1, anti-SR antibodies (Santa Cruz Biotechnology), and anti-phospho-tyrosine antibody (Cell Signaling Technology, Inc.). Both anti-PICK1 and anti-SR antibodies recognize the single band at the expected size of the proteins in the Western blotting.

Intrahippocampal infusion of ephrinB3 by the micro-osmotic pump. EphrinB3 $(10 \mu \mathrm{g} / \mathrm{ml})$ or vehicle control were loaded into osmotic pumps and connected to brain infusion kits (Alzet) and placed in PBS overnight at $37^{\circ} \mathrm{C}$. Male mice (ages 2-4 months) were anesthetized with ketamine and xylazine by intraperitoneal injection and positioned in a stereotaxic frame. Body temperature was monitored with a rectal probe and maintained at $37^{\circ} \mathrm{C}$ with a controlled heating pad set. A 1-mm-diameter craniotomy was made using a portable drill over the left parietotemporal cortex $(-2.3 \mathrm{~mm} \mathrm{~A} / \mathrm{P}$ and 1.1 $\mathrm{mm}$ lateral from bregma). Each infusion device was attached to the stereotactic holder and lowered $1.7 \mathrm{~mm}$ into the hippocampus and used for infusion over a $3 \mathrm{~d}$ period ( $100 \mu \mathrm{l}$ volume, rate $0.5 \mu \mathrm{l} / \mathrm{h}$ ). The pump was then fixed under the skin in the back of the neck. The incision was closed using Vetbond tissue adhesive $(3 \mathrm{M})$ and the animals were placed into a heated cage to maintain body temperature for $1 \mathrm{~h}$ postinjury.

\section{Results}

\section{Cultured hippocampal astrocytes express multiple B-class ephrins and Eph receptors}

Ephrins have been shown to play an important role in regulating synaptic plasticity in the adult hippocampus (Grunwald et al., 2004; Rodenas-Ruano et al., 2006); however, studies have not addressed whether these functions involve neuron-astrocyte interactions. Astrocytes are known to regulate synaptic activity and plasticity in the hippocampus through the release of D-serine (Haydon and Carmignoto, 2006; Bains and Oliet, 2007). To begin to address the role of ephrins and Eph receptors in D-serine release from astrocytes, we established an in vitro culture model and initially examined B-class ephrin and Eph receptor expression using immunohistochemical and RT-PCR approaches. After $14 \mathrm{~d}$ in culture, astrocyte cultures were highly pure as shown by GFAP expression (supplemental Fig. 1, available at www.jneurosci.org as supplemental material). Only a small fraction of cells $(<5 \%)$ were non-astrocytes including oligodendrocytes staining solely for the oligodendrocyte marker adenomatous polyposis coli tumor suppressor protein (APC), but not staining for GFAP (supplemental Fig. $1 A-C$, available at www.jneurosci.org as supplemental material), microglial cells expressing the microglia marker Ox42 (supplemental Fig. 1D-F, available at www. jneurosci.org as supplemental material), and neurons expressing the neuronal marker $\beta$-tubulin III (supplemental Fig. $1 G-I$, available at www.jneurosci.org as supplemental material). In examining ephrinB expression, we found that all three B-class ephrins were expressed in cultured astrocytes (Fig. 1A-C), where ephrinB2 and ephrinB3 were expressed in a punctate pattern in both the cell body and processes (Fig. $1 B, C$ ). We also found that astrocytes expressed EphB and EphA4 receptors, using a panEphB1-3 antibody (anti-pan-EphB1-3 antibody that recognizes EphB1, B2 and B3) as well as antibodies that specifically recognize EphB3 and EphA4 (Fig. 1D-F). Secondary antibodies showed no direct reactivity (supplemental Fig. $1 J-L$ ). To provide further evidence of ephrin and Eph expression in cultured astrocytes, we also examined mRNA expression using RT-PCR analysis. In par- 
ticular, mRNA transcripts for ephrin(B1, B2, B3) and $\mathrm{Eph}(\mathrm{B} 1, \mathrm{~B} 2, \mathrm{~B} 3$, and A4) were all observed to be present in cultured astrocytes (Fig. 1G). Positive controls used RNA extracted from neonatal whole brain, while RT-PCRs not containing reverse transcriptase were used as a negative control. These observations support a potential role for ephrins and Eph receptors in astrocytes.

\section{EphrinB3 activate EphB3 and EphA4 receptors to stimulate $\mathrm{D}$-serine release from cultured astrocytes}

To begin to implicate Eph receptors in regulating gliotransmitter release from hippocampal astrocytes, we examined whether stimulation of cultured astrocytes with soluble ephrins could alter D-serine release using chemiluminescent analysis (Fig. 2). Wild-type cultures incubated with $5 \mathrm{~mm}$ L-serine overnight were stimulated either with vehicle, $0.1 \mu \mathrm{g} / \mathrm{ml}$ ephrinB1 or ephrinB3 for 5 and $15 \mathrm{~min}$ (Fig. $2 \mathrm{~A}$ ). We observed a significant increase in D-serine level in the media at 5 and $15 \mathrm{~min}$ for both ephrinB1 and ephrinB3 stimulated cultures, which decreased by $30 \mathrm{~min}$ (data not shown). This decrease at longer incubation periods likely reflects active reuptake mechanisms and not degradation, since removal of media from cells for $30 \mathrm{~min}$ did not alter D-serine levels (data not shown). Next, we compared the optimal dose-dependent concentration of soluble ephrins, and observed the greatest increase in D-serine release for $0.1 \mu \mathrm{g} / \mathrm{ml}$ ephrinB1 and ephrinB3 (Fig. 2 B). To address Eph specificity, we examined whether ephrins could stimulate D-serine release in astrocytes deficient for two high-affinity receptors, EphB3 and EphA4, that are known to preferentially bind ephrinB3 (Blits-Huizinga et al., 2004). We observed a significant release of D-serine when cultures were stimulated with ephrinB1, but ephrinB3 stimulation had no effect (Fig. 2C). These studies support the specific interaction of ephrinB3 with EphB3 and EphA4 in regulating D-serine synthesis and/or release from astrocytes, and support the interaction of ephrinB1 through other Eph receptors. We focused on the interactions between ephrinB3 and its receptors, EphB3 and EphA4, for the subsequent studies, but do not exclude the possibility that ephrinB1 may also play an important role in $\mathrm{D}$-serine synthesis and release.
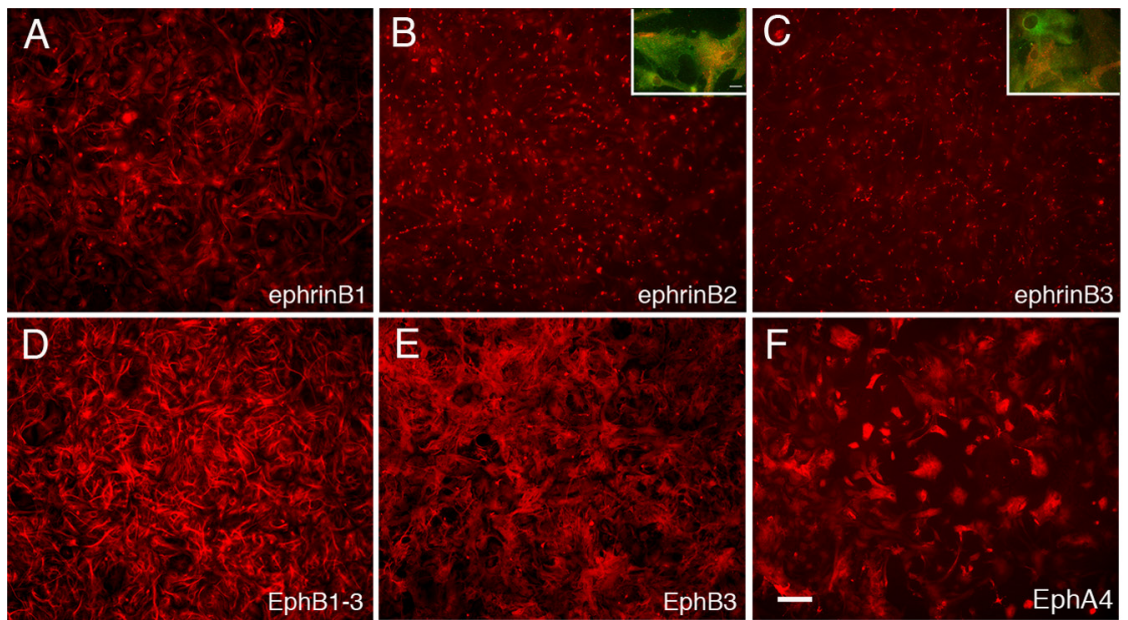

G

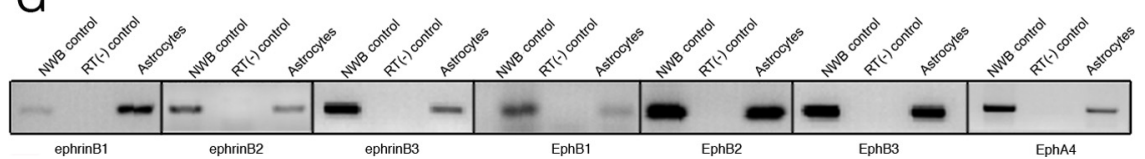

Figure 1. Expression of ephrins and Eph receptors in 14-d-old cultured astrocytes from wild-type mice. $\boldsymbol{A}-\boldsymbol{F}$, Immunoreactivity for ephrinB1 $(\boldsymbol{A})$, ephrinB2 $(\boldsymbol{B})$, ephrinB3 $(\boldsymbol{C})$, EphB1-3 $(\boldsymbol{D})$, EphB3 $(\boldsymbol{E})$, and EphA4 $(\boldsymbol{F})$ antibodies. Insets show punctate immunoreactivity for ephrinB2 (inset $\boldsymbol{B}$, red) and ephrinB3 (inset $\boldsymbol{C}$, red) costained with anti-GFAP (green). $\boldsymbol{G}, \mathrm{RT}-\mathrm{PCR}$ shows the expression of ephrinB1-3, EphB1-3, and EphA4 in cultured astrocytes. Scale bars: (in $\boldsymbol{F}$ ) $\boldsymbol{A}-\boldsymbol{F}, 100 \mu \mathrm{m}$; inset $\boldsymbol{B}, 20 \mu \mathrm{m}$.

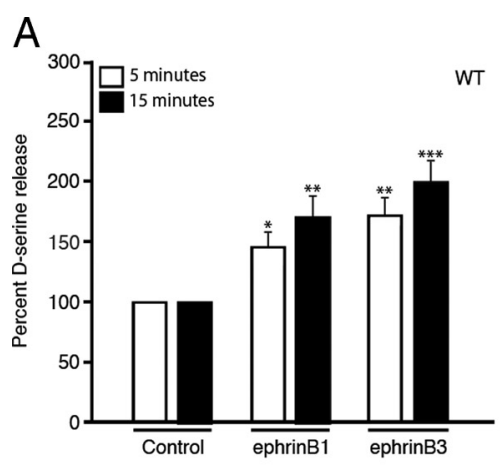

B

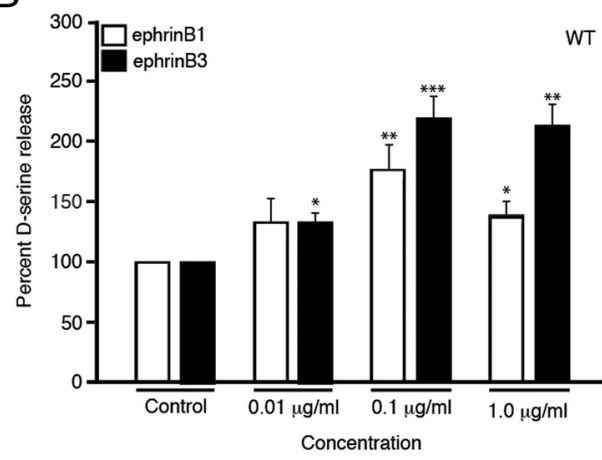

C

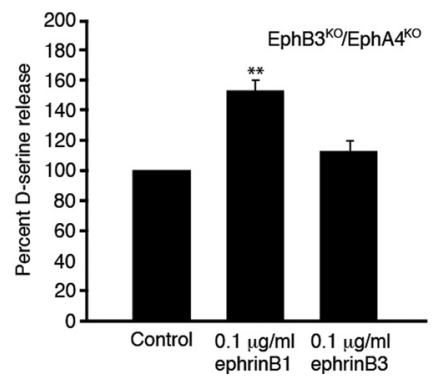

Figure 2. EphrinB1 and ephrinB3 stimulation increases D-serine release from wild-type astrocytes, but ephrinB3 has no effect on astrocytes derived from mice lacking EphB3 and EphA4.A-C, EphrinB1 and ephrinB3 increased D-serine release at 5 and 15 min $(\boldsymbol{A})$, where $0.1 \mu \mathrm{g} / \mathrm{ml}$ had a maximal effect $15 \mathrm{~min}$ after ephrinB3 application $(\boldsymbol{B})$. EphrinB1 but not ephrinB3 could stimulate D-serine release from astrocytes derived from EphB3 ${ }^{K O} / \mathrm{EphA}^{K O}$ mice $5 \mathrm{~min}$ after ephrinB3 application (C). D-Serine level is normalized against control $D$-serine level. $D$-Serine level in control media $5 \mathrm{~min}$ after ephrinB3 application is $14.3 \mathrm{~nm}$. Experiments were performed in triplicate $(\boldsymbol{A}$ and $\boldsymbol{B}, n=6-7 ; \boldsymbol{C}, n=13-14) .{ }^{*} p<0.05 ;{ }^{* *} p<0.01 ;{ }^{* * *} p<0.001$.
EphrinB3 enhances D-serine release by regulating serine racemase

To determine whether the Eph-mediated increase in D-serine release resulted from increased synthesis, we evaluated D-serine release following ephrinB3 stimulation in the presence of serine racemase inhibitors. SR is an enzyme that catalyzes the conversion of D-serine from L-serine (Martineau et al., 2006). Two pharmacological inhibitors, L-cycloserine and L-cysteine, have been identified to reduce SR activity and reduce D-serine release (Cook et al., 2002). We examined whether 20 and $200 \mu \mathrm{M} \mathrm{L}$-cycloserine 
A
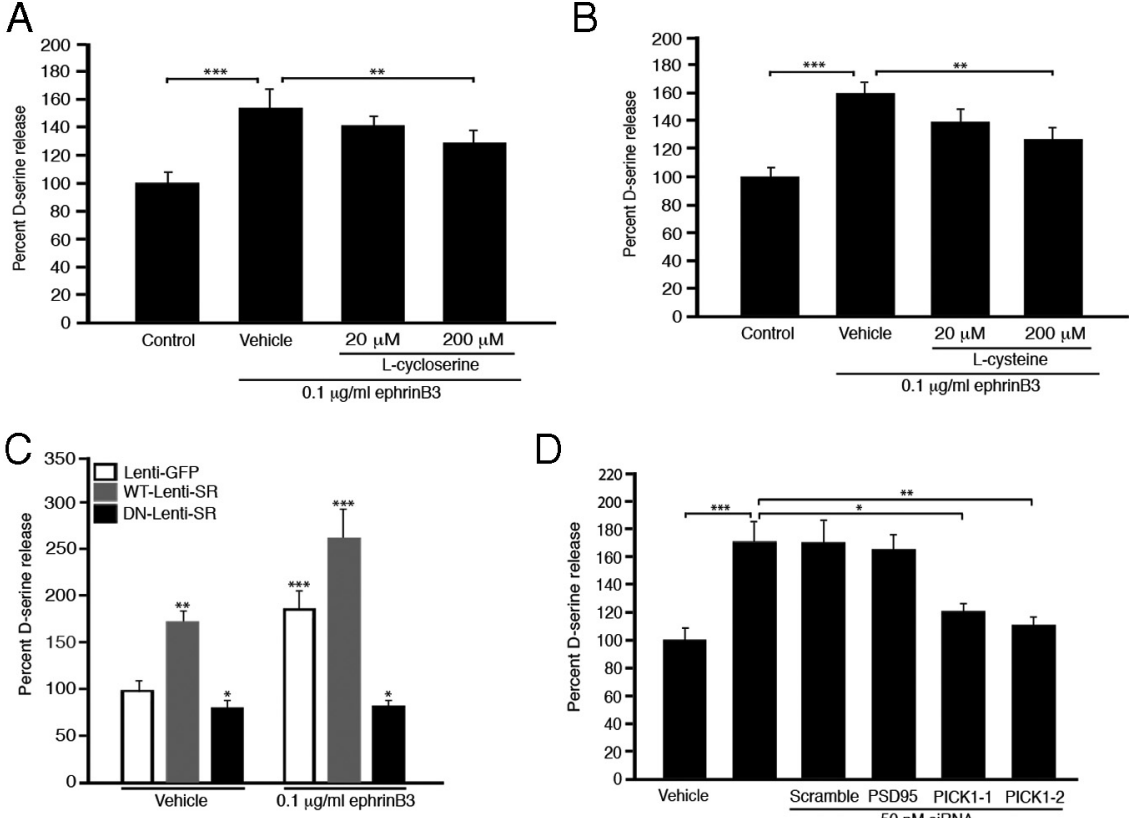

D

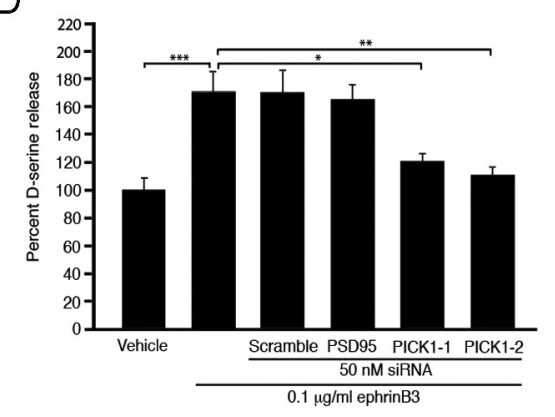

$E$

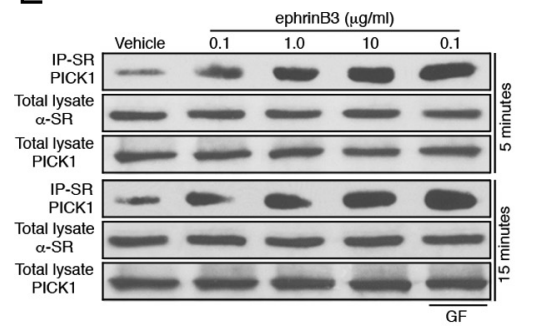

$F$

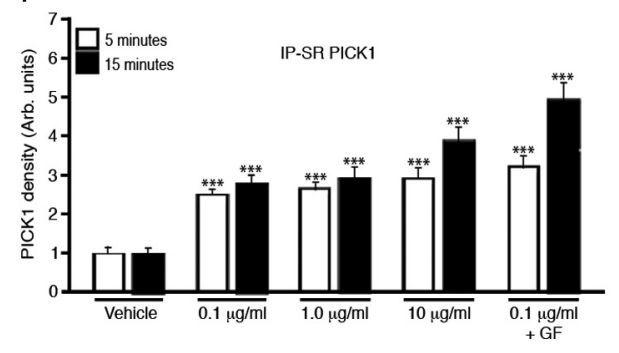

Figure 3. EphrinB3 increases D-serine synthesis and release through serine racemase and its association with PICK1 in astrocytes as well as through inactivation of PKC. $\boldsymbol{A}-\boldsymbol{C}$, Pharmacological inhibitors of serine racemase dose-dependently reduce $D$-serine release, where L-cycloserine $(\boldsymbol{A})$ and L-cysteine $(\boldsymbol{B})$ significantly inhibit the ephrinB3-mediated increase of D-serine release from cultured astrocytes $15 \mathrm{~min}$ after ephrinB3 application. Application of lentivirus encoding for a wild-type SR (WT-Lenti-SR) increased D-serine release 5 min after ephrinB3 application, while dominant-negative mutant SR (DN-Lenti-SR) reduced D-serine release in the presence and absence of ephrinB3 (C). D-F, PICK1 gene targeted knockdown using 50 nм PICK1-1 and PICK1-2 siRNA for $3 \mathrm{~d}$ can markedly reduce the increase of D-serine release after $15 \mathrm{~min}$ application of $0.1 \mu \mathrm{g} / \mathrm{ml}$ ephrinB3. Scrambled (nontargeting) and PSD95 siRNAs have no effect on ephrinB3-induced D-serine release $(\boldsymbol{D})$. Western blot analysis showed that ephrinB3 stimulation enhanced the association of SR with PICK1 in a dose-dependent manner, which was further augmented with the PKC inhibitor GF109203X (GF) (E). Densitometric quantification of Western blot $(\boldsymbol{F})$. Experiments were performed in triplicate $(\boldsymbol{A}-\boldsymbol{C}$, $n=13-14 ; \boldsymbol{D}-\boldsymbol{F} ; n=6-7) .{ }^{*} p<0.05 ;{ }^{* *} p<0.01 ;{ }^{* * *} p<0.001$.

or L-cysteine added 15 min before ephrinB3 stimulation could reduce ephrinB3-mediated increase in D-serine levels from cultured astrocytes. At $200 \mu \mathrm{M}$, we observed a significant $47.8 \%$ (L-cycloserine) and 56.4\% (L-cysteine) reduction in D-serine levels, as compared with vehicle treatment to baseline control levels (Fig. $3 A, B$ ). This suggests that the increased D-serine levels observed following ephrinB3 stimulation likely reflect D-serine synthesis. To provide a more direct examination of the role of SR, we generated lentiviruses that express dominant-negative (DN)and wild-type (WT)-SR. The DN-SR was generated by mutating the lysine in the Schiff base (K56G) that interferes with the pyridoxal-5' phosphate moiety and subsequent enzyme activity (Wolosker et al., 1999b). Forty-eight hours after viral transduction, we observed a significant increase in D-serine release following WT-SR expression compared with DN-SR and the vector-GFP control (Fig. 3C). Furthermore, DN-SR expression reduced D-serine release compared with the Lenti-GFP control. This supports the role of SR in the conversion of L-serine to D-serine and subsequent release of D-serine from cultured astrocytes. We also found that ephrinB3-application for 5 min could enhance D-serine release in the presence of the control and WT-SR but not DN-SR, suggesting that SR is critical for the ephrinB3mediated release of $\mathrm{D}$-serine. These findings support our hypothesis that ephrinB3 stimulates SR-mediated D-serine synthesis and release from cultured astrocytes.

EphrinB3 increases PICK1 interactions with SR, and modulates D-serine levels through inactivation of PKC $\alpha$.

To further evaluate how Eph receptors may modulate SR-dependent D-serine levels, we examined SR-interacting proteins such as glutamate receptor interacting protein (GRIP) and PICK1. We detected both GRIP and PICK1 in cultured astrocytes; however, only PICK1 was found to associate with SR by coimmunoprecipitation (Fig. $3 E, F$ ). Stimulation with 0.1 , 1.0 and $10 \mu \mathrm{g} / \mathrm{ml}$ ephrinB3 for 5 and 15 min resulted in a dose-dependent increase in the association of SR and PICK1, while no differences in protein concentration were observed in total lysate. We next examined whether PICK1 was essential in D-serine release using siRNA knockdown. PICK1 siRNA dose-dependently reduced PICK1 protein levels by $50 \%$ at $50 \mathrm{~nm}$ concentrations (supplemental Fig. 2, available at www.jneurosci.org as supplemental material). Reducing PICK1 RNA levels using two different PICK1 siRNAs before ephrinB3 stimulation lead to reduced D-serine release in cultured astrocytes, compared with knockdown of another PDZ-contained synaptic protein (i.e., PSD95 siRNA), scrambled siRNA, and vehicle controls (Fig. 3D). These findings support previous studies demonstrating the interactions of PDZ-containing proteins with SR, and further suggest that activation of Eph receptors enhances PICK1-SR interactions to regulate $\mathrm{D}$-serine release in cultured astrocytes.

Protein kinase C (PKC $\alpha$ ) also interacts with PICK1 and it has been speculated that this complex may result in the phosphorylation of SR by PKC $\alpha$; however, there is little to no evidence that PKC phosphorylates SR or that SR phosphorylation is required for enzymatic activity (Mustafa et al., 2004; Baumgart and Rodríguez-Crespo, 2008). PICK1 has one PDZ domain that is required for the interaction with $\mathrm{PKC} \alpha$, SR, or Eph receptors (Torres et al., 1998), so we examined whether PKC $\alpha$ activity was required for SR-PICK1 interactions. Figure 3, $E$ and $F$, shows that application of the PKC inhibitor GF109203X (GF) at a concentration of $2 \mathrm{nM}$ increased the amount of SR-PICK1 protein interactions compared with $0.1 \mu \mathrm{g} / \mathrm{ml}$ ephrinB3 alone. When GF was applied in the absence of ephrinB3 there was no effect on the association of SR and PICK1, suggesting that basal non-Ephmediated levels of SR-PICK1 interactions are PKC independent (supplemental Fig. 3A, available at www.jneurosci.org as supple- 
mental material). Similarly, GF alone had no effect on the protein levels of PKC $\alpha$, PICK1, and SR from total lysates, or on D-serine release (supplemental Fig. $3 B, C$, available at www.jneurosci.org as supplemental material). Interestingly, previous studies by our laboratory showed that $\mathrm{p}$-PKC $\alpha$ levels are increased in hippocampal tissues in the absence of ephrinB3 (Rodenas-Ruano et al., 2006), suggesting that Eph receptors may negatively regulate PKC $\alpha$ activation. To determine whether ephrinB3 can negatively regulate PKC $\alpha$ phosphorylation, we examined the levels of p-PKC $\alpha$ in cultured astrocytes stimulated for 5, 15, and $30 \mathrm{~min}$. Figure 4, $A$ and $B$, shows that stimulation with 0.1 and 1.0 $\mu \mathrm{g} / \mathrm{ml}$ soluble ephrinB3 for 5-30 $\mathrm{min}$ could significantly reduce the levels of p-PKC $\alpha$ without altering total $\operatorname{PKC} \alpha$. We also examined whether inactivating PKC $\alpha$ leads to increased D-serine following ephrinB3 stimulation in cultured astrocytes, and found that 2 or $20 \mathrm{nM} \mathrm{GF}$ enhanced D-serine levels in both the cell lysate and media following application of $0.1 \mu \mathrm{g} / \mathrm{ml}$ ephrinB3 for $15 \mathrm{~min}$ (Fig. 4C). These findings suggest that Eph receptors regulate D-serine levels by reducing PKC $\alpha$ activity to enhance SR-PICK1 interactions. It is currently unclear how $\mathrm{p}-\mathrm{PKC} \alpha$ interferes with SR-PICK1 complex or D-serine levels, since we have been unable to identify whether PKC $\alpha$ acts directly on SR or whether SR phosphorylation is required for SR activity.

\section{EphrinB3-induced phosphorylation of EphB3 and/or EphA4 mediates D-serine secretion through reduction of Eph receptors interactions with PICK1}

To differentiate between the role of EphB3 and EphA4 in regulating D-serine release, we examined whether ephrinB3 stimulates phosphorylation of EphB3 and EphA4 in cultured astrocytes. Using Eph receptor pull down and anti-phospho-tyrosine immunoblots, we observed a dose-dependent enhancement in EphB3 phosphorylation after $5 \mathrm{~min}$ stimulation with 0.1 and $1.0 \mu \mathrm{g} / \mathrm{ml}$ ephrinB3 (Fig. $5 A, B$ ). We did not observe increased phosphorylation of EphA4 using similar conditions (data not shown), which may reflect differences in binding affinity and activation. It is also unclear whether Eph phosphorylation is required for enhancing $\mathrm{D}$-serine release through interactions with $\mathrm{PKC} \alpha$, but PICK1 is a PDZ-containing protein that interacts with Eph-PDZ domain independent of tyrosine phosphorylation. To examine whether ephrinB3 treatment results in a change in PICK1-Eph association, we used co-IP and found that ephrinB3 stimulation markedly reduced EphB3-PICK1 association at both 0.1 and $1.0 \mu \mathrm{g} / \mathrm{ml}$ concentrations (Fig. $5 A, C$ ), whereas only $1.0 \mu \mathrm{g} / \mathrm{ml}$ ephrinB3 reduced EphA4-PICK1 association (Fig. $5 D, E$ ). These findings support the reduced sensitivity of EphA4 to ephrinB3 stimulation compared with EphB3. To further evaluate the relative significances of EphB3 and EphA4, we examined the role of each individual receptor in regulating $\mathrm{D}$-serine release following stimulation of EphB3 $3^{K O}$ or EphA4 ${ }^{K O}$ astrocytes with 0.1 and 1.0 $\mu \mathrm{g} / \mathrm{ml}$ ephrinB3 (Fig. $5 F$ ). We observed an increase in D-serine release in EphA4 ${ }^{\mathrm{KO}}$ (EphB3 still present) at 0.1 and $1.0 \mu \mathrm{g} / \mathrm{ml}$ ephrinB3 but only in EphB3 ${ }^{\mathrm{KO}}$ (EphA4 still present) astrocytes at the highest ephrinB3 concentration $(1.0 \mu \mathrm{g} / \mathrm{ml})$, suggesting that
EphB3 may play a more prominent role in ephrinB3-mediated D-serine release although both receptors are important.

\section{EphrinB3 interacts with EphB3 and EphA4 to increase D-serine levels in the hippocampus}

To determine whether ephrinB3 can stimulate EphB3 and EphA4 to regulate $\mathrm{D}$-serine levels in the adult hippocampus, we first examined whether hippocampal astrocytes expressed Eph receptors. Figure $6 A-F$ shows that GFAP-positive astrocytes in the adult hippocampus colabel for $\mathrm{Eph}(\mathrm{B} 1, \mathrm{~B} 2$ and B3) and EphA4. We also observed expression of SR in hippocampal astrocytes (supplemental Fig. 4, available at www.jneurosci.org as supplemental material). To evaluate the role of Eph receptors on D-serine levels, wild-type and EphB3 ${ }^{K O} / E p h A 4^{K O}$ mice were infused with $10 \mu \mathrm{g} / \mathrm{ml}$ ephrinB3 for $3 \mathrm{~d}$, brains were snap-frozen, the CA1 regions of the hippocampus were punched out, and total levels of D-serine were measured. We observed a significant increase in D-serine in wild-type mice following ephrinB3 infusion that was not observed in EphB3 ${ }^{K O} / E p h A 4^{K O}$ mice (Fig. 6G). To demonstrate that increased $\mathrm{D}$-serine release was activity-dependent, we stimulated acute hippocampal slices with 1 and $10 \mathrm{mM}$ glutamate for $15 \mathrm{~min}$ from wild-type and $E p h B 3^{K O} / E p h A 4^{K O}$ mice. We observed a significant increase in $\mathrm{D}$-serine release in glutamate-stimulated hippocampal slices harvested from wildtype but not EphB3 $3^{K O} / E p h A 4^{K O}$ mice (Fig. $6 H$ ), supporting the role of Eph receptors in activity-dependent D-serine release. We also found that hippocampal slices from EphB3 ${ }^{K O} / E p h A 4^{K O}$ mice showed reduced ability to undergo enhancement of synaptic transmission following titanic stimulation compared with slices from wild-type mice (Fig. 6I). Impaired synaptic potentiation in knock-out mice occurred immediately after tetanic stimulation suggesting involvement of processes involved in post-tetanic potentiation (PTP). Although reduced intensity was observed, synaptic potentiation in knock-out hippocampus remained at $2 \mathrm{~h}$, indicating that the induction and maintenance of LTP remained intact. In contrast there was significant paired pulse facilitation in both wild-type and knock-out mice ( $F=$ 14.3, $p<0.001, n=4$ ) but no differences between the two genotypes $(F=0.03, p>0.05, n=4)$ (data not shown). Finally, we examined whether there was an alteration in the association of PICK1 and SR in the absence of Eph receptors. Consistent with 
A

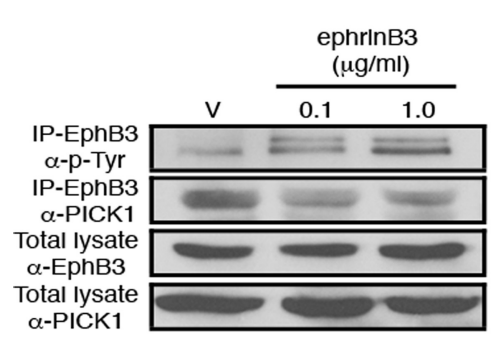

D

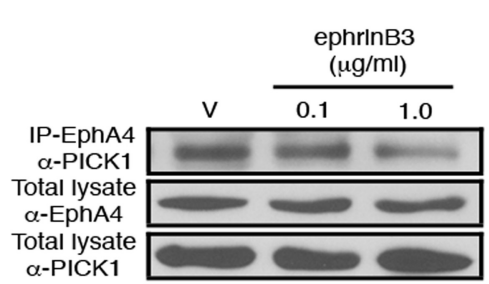

B

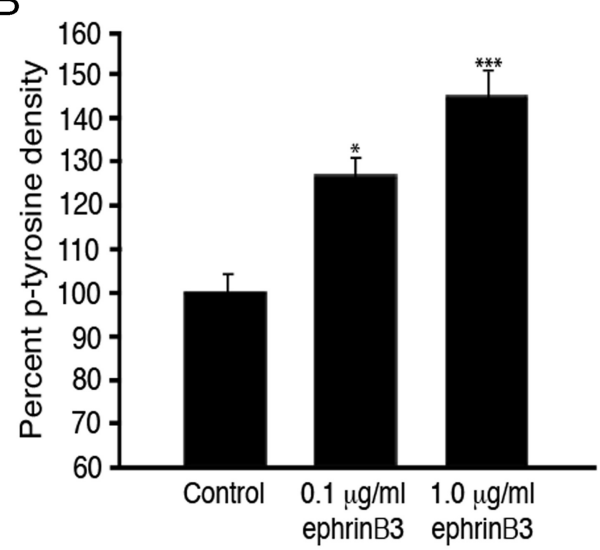

E

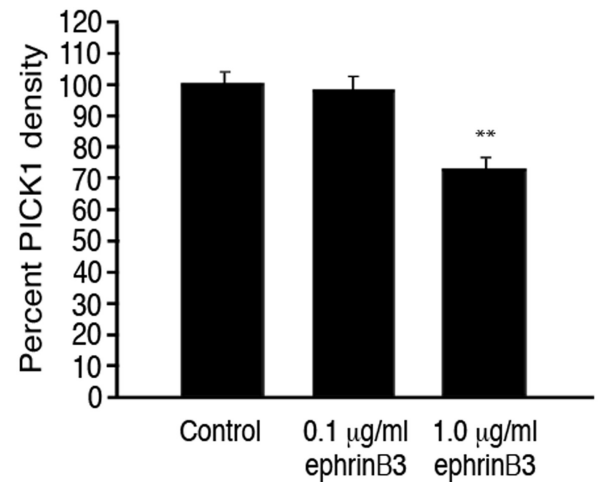

C

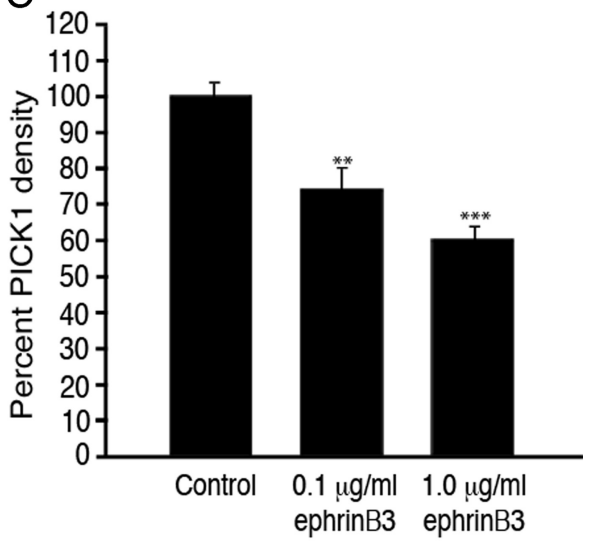

$\mathrm{F}$

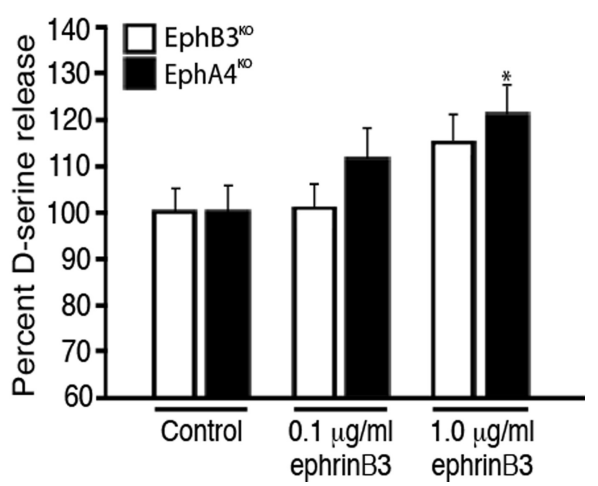

Figure 5. EphrinB3 regulates D-serine levels predominantly through activation of EphB3; however, both EphB3 and EphA4 associate with PICK1 and are involved in D-serine release. $\boldsymbol{A}$ - $\boldsymbol{C}$, Increased tyrosine phosphorylation of EphB3 after 5 min exposure to 0.1 and $1.0 \mu \mathrm{g} / \mathrm{ml}$ ephrinB3 correlated with a reduction in EphB3:PICK1 association in cultured astrocytes. $\boldsymbol{D}, \boldsymbol{E}, \mathbf{S t i m u l a t i o n}$ of EphA4 with ephrinB3 also dissociated EphA4:PICK1, but only when stimulated for 5 min with $1.0 \mu \mathrm{g} / \mathrm{ml}$ ephrinB3. $\boldsymbol{F}$, Application of $1.0 \mu \mathrm{g} / \mathrm{ml}$ ephrinB3 significantly increased D-serine release in cultured astrocytes from EphA4 ${ }^{K O}$ mice, whereas no differences were observed in $E p h B 3{ }^{K O}$ mice or with lower concentrations (i.e., $\left.0.1 \mu \mathrm{g} / \mathrm{ml}\right)$ of ephrinB3 (C). (A and $\left.\boldsymbol{B}, n=6 ; \boldsymbol{C}, n=9\right)$. ${ }^{*} p<0.05$; ${ }^{* *} p<0.01 ;{ }^{* * *} p<0.001$.

enhanced D-serine release and reduced synaptic activity, we observed a $26 \%$ reduction $(p<0.01)$ in PICK1-SR interaction in EphB3 ${ }^{\mathrm{KO}} / \mathrm{EphA} 4{ }^{\mathrm{KO}}$ mice compared with wild-type littermates (Fig. 6J). Together, these in vivo findings provide evidence for the regulatory functions of Eph receptors on transmitter release.

\section{Discussion}

In the present study, we have demonstrated that ephrinB3 can induce D-serine synthesis and release from astrocytes through activation of EphB3/EphA4 receptors. Our conclusion is based on several compelling arguments: (1) Eph receptors are expressed in vitro and in vivo on hippocampal astrocytes; (2) ephrinB3 can stimulate D-serine release from wild-type astrocyte cultures but not from astrocytes derived from EphB3 ${ }^{K O} / E p h A 4^{K O}$ mice; (3) infusion of ephrinB3 in the hippocampus leads to a similar increase in D-serine levels in wild-type but not EphB3 ${ }^{K O} / E p h A 4^{K O}$ mice; (4) SR is a key mediator of D-serine levels since pharmacological inhibitors of serine racemase and DN-SR blocked release whereas WT-SR enhanced release; (5) activation of Eph receptors leads to reduced Eph-PICK1 and enhanced SR-PICK1 interactions, which is further augmented when $\mathrm{PKC} \alpha$ activity is reduced; (6) activation of Eph receptors leads to dephosphorylation of $\mathrm{PKC} \alpha$, which increases D-serine synthesis and release; and (7) deficiencies in EphB3 and EphA4 result in reduced LTP compared with wild-type littermates. Together these studies show a new and novel role for Eph receptors in regulating
D-serine release from astrocytes that may function to modulate synaptic activity.

While glutamate is the most studied member among gliotransmitters, D-serine has recently emerged as an important mediator of synaptic function (Martineau et al., 2006). D-Serine is described as a coactivator for the glycine binding site on postsynaptic NMDA receptors (Mustafa et al., 2004). Along with glutamate, endogenous $\mathrm{D}$-serine mediates the long-term potentiation in the hippocampus, a region associated with learning and memory (Yang et al., 2003, 2005; Junjaud et al., 2006; Mothet et al., 2006). In the supraoptic nucleus, astrocyte-derived D-serine directly affects NMDA excitatory transmission and synaptic plasticity (Panatier et al., 2006a). Recent studies by Henneberger et al. (2010) demonstrate that gliotransmitters originate from astrocytes that occupy distinct nonoverlapping territories, where increases in astrocyte $\mathrm{Ca}^{2+}$ concentrations trigger D-serine release in nearby synapses. While our studies do not address the role of $\mathrm{Ca}^{2+}$ in mediating $\mathrm{D}$-serine release, they do show that activation of membrane-bound Eph receptors in astrocytes may be important in the activation of SR and subsequent synthesis and release of D-serine. Lending to the possibility that synaptic activity may be regulated through direct communication between ephrins and Ephs on presynaptic, postsynaptic and astrocytic membranes. Numerous studies have shown that ephrins and Eph receptors play pivotal roles in synaptic formation, transmission and plas- 
ticity (Klein, 2009) and we here have shown that EphB3 ${ }^{K O} / E p h A 4^{K O}$ mice have reduced LTP; however, additional studies are needed to determine whether these ephrin(neuron)-Eph(astrocyte) interactions are required for regulation of synaptic functions.

It is known that SR is a key enzyme in D-serine synthesis, since SR deficient mice show a $\sim 90 \%$ decrease in forebrain D-serine content (Inoue et al., 2008). SR activity has been shown to be regulated by two adaptor proteins, PICK1 and GRIP, which bind directly to SR (Kim et al., 2005; Fujii et al., 2006). In neurons, ephrins and Ephs can associate with some scaffolding and adapter proteins that regulate AMPA receptor trafficking, including GRIPs and PICK1 (Song and Huganir, 2002). GRIP proteins interact with AMPA receptors by means of PDZ domains, and facilitate surface accumulation of AMPA receptors at synapses by association with the GluR2/3 subunit (Setou et al., 2002). Activation of AMPA receptors leads to dissociation of GRIP and increased binding with SR, which in turn increases the production of D-serine (Kim et al., 2005). Similarly, EphrinBs/Ephs can also interact with the PDZ domains of GRIP1 (Brückner et al., 1999), and GRIP1 knockdown in hippocampal neurons inhibits the surface expression of EphB2 (Hoogenraad et al., 2005). In the absence of ephrinB3, we previously observed a significant increase in the levels of membrane-associated GRIP (Rodenas-Ruano et al., 2006); however, we did not observe a significant interaction of GRIP association with SR in the presence or absence of ephrinB3 stimulation. This may suggest that either GRIP may play a more important role in regulating AMPA-mediated interactions with $\mathrm{SR}$, have different roles in neurons versus astrocytes, and/or primarily function to stabilize proteins associated with the astrocyte plasma membrane. Furthermore, since ephrinB1 could also stimulate D-serine release we cannot rule out the possibility the EphB1 and EphB2 may also function to regulate SR activity, and these receptors may have different signaling intermediates than EphB3 and EphA4.

In addition to GRIPs, PICK1 also regulates the subcellular localization and surface expression of synaptic proteins including AMPA (Perez et al., 2001) and interacts with SR (Fujii et al., 2006). PICK1-SR interactions require the $\mathrm{PDZ}$ domain of PICK1 and the C terminus of SR; however, the role of PICK1 in regulating SR activity remains unclear. We have demonstrated that PICK1 can associate with Eph
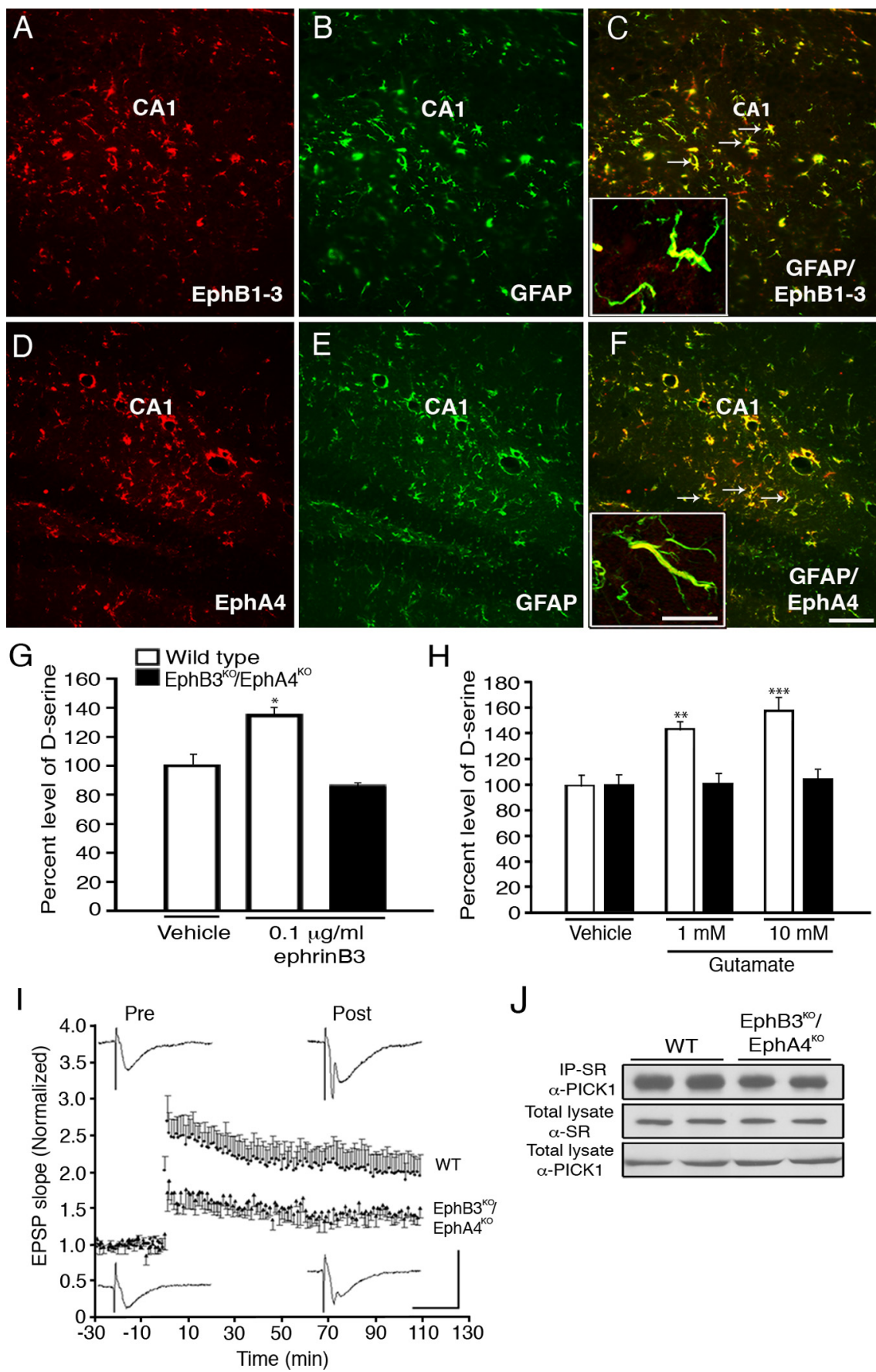

J

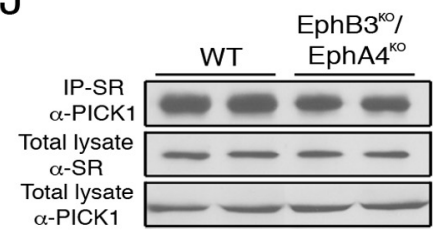

Figure 6. EphB3 and EphA4 receptors expressed in the adult hippocampus are involved in the regulation of D-serine levels and synaptic transmission. $\boldsymbol{A}-\boldsymbol{J}$, Immunoreactivity for EphB1-3 (A, red), GFAP (B, green), and merged image show colocalization of GFAP and EphB1-3 (C). Immunoreactivity for EphA4 (D, red), GFAP ( $\boldsymbol{E}$, green), and merged image show colocalization of GFAP and EphA4 $(\boldsymbol{F})$. Insets show confocal images of astrocyte processes where GFAP is colocalized with EphB1-3 (C) or EphA4 (F). EphrinB3 (10 $\mu \mathrm{g} / \mathrm{ml})$ was delivered to one side of the hippocampus using micro-osmotic pumps for $3 \mathrm{~d}$, which increased D-serine levels in the hippocampus of wild-type but not EphB3 ${ }^{K O} / E p h A 4^{K O}$ mice (G). Stimulation of acute hippocampal slices with glutamate enhanced D-serine release from wild-type but not EphB3 ${ }^{K O} / E p h A 4^{K O}$ mice $(\boldsymbol{H})$. D-Serine level was normalized against vehicle control D-serine level. D-Serine level in wild-type hippocampal lysate $36 \mathrm{~h}$ after vehicle application was $4.93 \mathrm{pmol} / \mathrm{mg}$ protein. D-Serine level in control media $15 \mathrm{~min}$ after ephrinB3 application was $7.6 \mathrm{~nm}$. Post-tetanic potentiation was significantly impaired in hippocampal slices from EphB3 ${ }^{K O} / E p h A 4^{K O}$ mice $(\boldsymbol{J})$. Normalized EPSP slopes (individual EPSP slope/mean pre-tetanus EPSP slope) before and after tetanic stimulation in hippocampal slices from wild-type and EphB3 ${ }^{K O} / E p h A 4^{K O}$ mice. Insets show examples of EPSP from both wild-type and knock-out hippocampal slices before and after tetanic stimulation. Calibration bars: vertical, $3 \mathrm{mV}$; horizontal, $20 \mathrm{~ms}(I)$. The association of SR with PICK1 was attenuated in the EphB3 ${ }^{\mathrm{K} 0} / \mathrm{EphA4}{ }^{\mathrm{K} 0}$ mice $(\boldsymbol{J})$. Scale bars $(\boldsymbol{F}), 100 \mu \mathrm{m}$; inset, $10 \mu \mathrm{m}$. $\boldsymbol{G}$ and $\boldsymbol{H}, n=6$; and I, J, $n=4 .{ }^{*} p<0.05 ;{ }^{* *} p<0.01$; ${ }^{* * *} p<0.001$. 
receptors in astrocytes as previously described for neurons (Torres et al., 1998), and upon receptor activation there is a dissociation of PICK1 from Eph and increased association with SR. PICK1 was initially identified as a PDZ-containing protein that interacts with the catalytic domain of PKC $\alpha$ (Staudinger et al., 1995), and it is proposed that PICK1 may escort PKC $\alpha$ to SR for phosphorylation and enzymatic activation (Fujii et al., 2006). This conclusion mainly results from the ability of PICK1 to associate with $\mathrm{PKC} \alpha$ and its proximity to SR, but there is no direct evidence that SR is phosphorylated by $\mathrm{PKC} \alpha$ (Baumgart and Rodríguez-Crespo, 2008). Our findings contradict this possibility where inactivation of PKC $\alpha$ may be important for both SR-PICK1 binding as well as D-serine synthesis and release. Recent studies by R. A. Panizzutti (personal communication) have demonstrated that activated PKC $\alpha$ can inhibit D-serine synthesis and release through the phosphorylation of SR, supporting our findings that the pharmacological PKC inhibitor (GF109203X) may enhance D-serine synthesis and release following ephrinB3 stimulation. Additional mutational studies of the SR phosphorylation site would help address the role of $\mathrm{p}$-SR in D-serine production. Furthermore, we cannot rule out the possibility that $\mathrm{p}-\mathrm{PKC} \alpha$ and PICK1 may function independent of SR to directly regulate vesicle release of D-serine in astrocytes.

Here, we demonstrate that ephrinB3 regulates D-serine levels in the hippocampus through its interaction predominantly with EphB3 but also EphA4 receptors. Activation of Eph receptors leads to reduced PICK1-Eph association and dephosphorylation of $\mathrm{PKC} \alpha$, increased PICK1-SR interactions, and enhanced D-serine synthesis and release. In the absence of Eph signaling, D-serine release and synaptic transmission are attenuated. These findings may have important implications on how neurons regulate astrocyte gliotransmitter levels to modulate synaptic transmission and plasticity.

\section{References}

Angulo MC, Kozlov AS, Charpak S, Audinat E (2004) Glutamate released from glial cells synchronizes neuronal activity in the hippocampus. J Neurosci 24:6920-6927.

Aoto J, Ting P, Maghsoodi B, Xu N, Henkemeyer M, Chen L (2007) Postsynaptic ephrinB3 promotes shaft glutamatergic synapse formation. J Neurosci 27:7508-7519.

Araque A, Parpura V, Sanzgiri RP, Haydon PG (1999) Tripartite synapses: glia, the unacknowledged partner. Trends Neurosci 22:208-215.

Bains JS, Oliet SH (2007) Glia: they make your memories stick! Trends Neurosci 30:417-424.

Baumgart F, Rodríguez-Crespo I (2008) D-amino acids in the brain: the biochemistry of brain serine racemase. FEBS J 275:3538-3545.

Blits-Huizinga CT, Nelersa CM, Malhotra A, Liebl DJ (2004) Ephrins and their receptors: binding versus biology. IUBMB Life 56:257-265.

Brückner K, Pablo Labrador J, Scheiffele P, Herb A, Seeburg PH, Klein R (1999) EphrinB ligands recruit GRIP family PDZ adaptor proteins into raft membrane microdomains. Neuron 22:511-524.

Cook SP, Galve-Roperh I, Martínez del Pozo A, Rodríguez-Crespo I (2002) Direct calcium binding results in activation of brain serine racemase. J Biol Chem 277:27782-27792.

Cotrina ML, Lin JH, López-García JC, Naus CC, Nedergaard M (2000) ATP-mediated glia signaling. J Neurosci 20:2835-2844.

Fellin T, Carmignoto G (2004) Neurone-to-astrocyte signalling in the brain represents a distinct multifunctional unit. J Physiol 559:3-15.

Fields RD, Stevens-Graham B (2002) New insights into neuron-glia communication. Science 298:556-562.

Foltyn VN, Bendikov I, De Miranda J, Panizzutti R, Dumin E, Shleper M, Li P, Toney MD, Kartvelishvily E, Wolosker H (2005) Serine racemase modulates intracellular D-serine levels through an alpha, beta-elimination activity. J Biol Chem 280:1754-1763.

Fujii K, Maeda K, Hikida T, Mustafa AK, Balkissoon R, Xia J, Yamada T, Ozeki Y, Kawahara R, Okawa M, Huganir RL, Ujike H, Snyder SH, Sawa
A (2006) Serine racemase binds to PICK1: potential relevance to schizophrenia. Mol Psychiatry 11:150-157.

Gale NW, Holland SJ, Valenzuela DM, Flenniken A, Pan L, Ryan TE, Henkemeyer M, Strebhardt K, Hirai H, Wilkinson DG, Pawson T, Davis S, Yancopoulos GD (1996) Eph receptors and ligands comprise two major specificity subclasses and are reciprocally compartmentalized during embryogenesis. Neuron 17:9-19.

Gordon GR, Baimoukhametova DV, Hewitt SA, Rajapaksha WR, Fisher TE, Bains JS (2005) Norepinephrine triggers release of glial ATP to increase postsynaptic efficacy. Nat Neurosci 8:1078-1086.

Grunwald IC, Korte M, Adelmann G, Plueck A, Kullander K, Adams RH, Frotscher M, Bonhoeffer T, Klein R (2004) Hippocampal plasticity requires postsynaptic ephrinBs. Nat Neurosci 7:33-40.

Halassa MM, Fellin T, Haydon PG (2007) The tripartite synapse: roles for gliotransmission in health and disease. Trends Mol Med 13:54-63.

Haydon PG (2001) GLIA: listening and talking to the synapse. Nat Rev Neurosci 2:185-193.

Haydon PG, Carmignoto G (2006) Astrocyte control of synaptic transmission and neurovascular coupling. Physiol Rev 86:1009-1031.

Helmbacher F, Schneider-Maunoury S, Topilko P, Tiret L, Charnay P (2000) Targeting of the EphA4 tyrosine kinase receptor affects dorsal/ventral pathfinding of limb motor axons. Development 127:3313-3324.

Henkemeyer M, Orioli D, Henderson JT, Saxton TM, Roder J, Pawson T, Klein R (1996) Nuk controls pathfinding of commissural axons in the mammalian central nervous system. Cell 86:35-46.

Henkemeyer M, Itkis OS, Ngo M, Hickmott PW, Ethell IM (2003) Multiple EphB receptor tyrosine kinases shape dendritic spines in the hippocampus. J Cell Biol 163:1313-1326.

Henneberger C, Papouin T, Oliet SH, Rusakov DA (2010) Long-term potentiation depends on release of D-serine from astrocytes. Nature 463:232-236.

Hoogenraad CC, Milstein AD, Ethell IM, Henkemeyer M, Sheng M (2005) GRIP1 controls dendrite morphogenesis by regulating EphB receptor trafficking. Nat Neurosci 8:906-915.

Inoue R, Hashimoto K, Harai T, Mori H (2008) NMDA- and betaamyloid1-42-induced neurotoxicity is attenuated in serine racemase knock-out mice. J Neurosci 28:14486-14491.

Iwasato T, Katoh H, Nishimaru H, Ishikawa Y, Inoue H, Saito YM, Ando R, Iwama M, Takahashi R, Negishi M, Itohara S (2007) Rac-GAP alphachimerin regulates motor-circuit formation as a key mediator of EphrinB3/EphA4 forward signaling. Cell 130:742-753.

Jevince AR, Kadison SR, Pittman AJ, Chien CB, Kaprielian Z (2006) Distribution of $\mathrm{EphB}$ receptors and ephrin-B1 in the developing vertebrate spinal cord. J Comp Neurol 497:734-750.

Jourdain P, Bergersen LH, Bhaukaurally K, Bezzi P, Santello M, Domercq M, Matute C, Tonello F, Gundersen V, Volterra A (2007) Glutamate exocytosis from astrocytes controls synaptic strength. Nat Neurosci 10:331-339.

Junjaud G, Rouaud E, Turpin F, Mothet JP, Billard JM (2006) Age-related effects of the neuromodulator D-serine on neurotransmission and synaptic potentiation in the CA1 hippocampal area of the rat. J Neurochem 98:1159-1166.

Kim PM, Aizawa H, Kim PS, Huang AS, Wickramasinghe SR, Kashani AH, Barrow RK, Huganir RL, Ghosh A, Snyder SH (2005) Serine racemase: activation by glutamate neurotransmission via glutamate receptor interacting protein and mediation of neuronal migration. Proc Natl Acad Sci U S A 102:2105-2110.

Klein R (2009) Bidirectional modulation of synaptic functions by Eph/ephrin signaling. Nat Neurosci 12:15-20.

Martineau M, Baux G, Mothet JP (2006) D-serine signalling in the brain: friend and foe. Trends Neurosci 29:481-491.

Mothet JP, Parent AT, Wolosker H, Brady RO Jr, Linden DJ, Ferris CD, Rogawski MA, Snyder SH (2000) D-serine is an endogenous ligand for the glycine site of the $\mathrm{N}$-methyl-D-aspartate receptor. Proc Natl Acad Sci U S A 97:4926-4931.

Mothet JP, Pollegioni L, Ouanounou G, Martineau M, Fossier P, Baux G (2005) Glutamate receptor activation triggers a calcium-dependent and SNARE protein-dependent release of the gliotransmitter D-serine. Proc Natl Acad Sci U S A 102:5606-5611.

Mothet JP, Rouaud E, Sinet PM, Potier B, Jouvenceau A, Dutar P, Videau C, Epelbaum J, Billard JM (2006) A critical role for the glial-derived neu- 
romodulator D-serine in the age-related deficits of cellular mechanisms of learning and memory. Aging Cell 5:267-274.

Mustafa AK, Kim PM, Snyder SH (2004) D-Serine as a putative glial neurotransmitter. Neuron Glia Biol 1:275-281.

Neary JT, Whittemore SR, Zhu Q, Norenberg MD (1994) Synergistic activation of DNA synthesis in astrocytes by fibroblast growth factors and extracellular ATP. J Neurochem 63:490-494.

Newman EA (2003) Glial cell inhibition of neurons by release of ATP. J Neurosci 23:1659-1666.

Panatier A, Gentles SJ, Bourque CW, Oliet SH (2006a) Activity-dependent synaptic plasticity in the supraoptic nucleus of the rat hypothalamus. J Physiol 573:711-721.

Panatier A, Theodosis DT, Mothet JP, Touquet B, Pollegioni L, Poulain DA, Oliet SH (2006b) Glia-derived D-serine controls NMDA receptor activity and synaptic memory. Cell 125:775-784.

Pasquale EB (2008) Eph-ephrin bidirectional signaling in physiology and disease. Cell 133:38-52.

Perez JL, Khatri L, Chang C, Srivastava S, Osten P, Ziff EB (2001) PICK1 targets activated protein kinase Calpha to AMPA receptor clusters in spines of hippocampal neurons and reduces surface levels of the AMPAtype glutamate receptor subunit 2. J Neurosci 21:5417-5428.

Rodenas-Ruano A, Perez-Pinzon MA, Green EJ, Henkemeyer M, Liebl DJ (2006) Distinct roles for ephrinB3 in the formation and function of hippocampal synapses. Dev Biol 292:34-45.

Schell MJ, Brady RO Jr, Molliver ME, Snyder SH (1997) D-serine as a neuromodulator: regional and developmental localizations in rat brain glia resemble NMDA receptors. J Neurosci 17:1604-1615.

Setou M, Seog DH, Tanaka Y, Kanai Y, Takei Y, Kawagishi M, Hirokawa N (2002) Glutamate-receptor-interacting protein GRIP1 directly steers kinesin to dendrites. Nature 417:83-87.

Shleper M, Kartvelishvily E, Wolosker H (2005) D-serine is the dominant endogenous coagonist for NMDA receptor neurotoxicity in organotypic hippocampal slices. J Neurosci 25:9413-9417.

Song I, Huganir RL (2002) Regulation of AMPA receptors during synaptic plasticity. Trends Neurosci 25:578-588.

Staudinger J, Zhou J, Burgess R, Elledge SJ, Olson EN (1995) PICK1: a pe- rinuclear binding protein and substrate for protein kinase $\mathrm{C}$ isolated by the yeast two-hybrid system. J Cell Biol 128:263-271.

Stevens ER, Esguerra M, Kim PM, Newman EA, Snyder SH, Zahs KR, Miller RF (2003) D-serine and serine racemase are present in the vertebrate retina and contribute to the physiological activation of NMDA receptors. Proc Natl Acad Sci U S A 100:6789-6794.

Torres R, Firestein BL, Dong H, Staudinger J, Olson EN, Huganir RL, Bredt DS, Gale NW, Yancopoulos GD (1998) PDZ proteins bind, cluster, and synaptically colocalize with Eph receptors and their ephrin ligands. Neuron 21:1453-1463.

Ventura R, Harris KM (1999) Three-dimensional relationships between hippocampal synapses and astrocytes. J Neurosci 19:6897-6906.

Volterra A, Meldolesi J (2005) Astrocytes, from brain glue to communication elements: the revolution continues. Nat Rev Neurosci 6:626-640.

Wolosker H, Sheth KN, Takahashi M, Mothet JP, Brady RO Jr, Ferris CD, Snyder SH (1999a) Purification of serine racemase: biosynthesis of the neuromodulator D-serine. Proc Natl Acad Sci U S A 96:721-725.

Wolosker H, Blackshaw S, Snyder SH (1999b) Serine racemase: a glial enzyme synthesizing D-serine to regulate glutamate- $N$-methyl-D-aspartate neurotransmission. Proc Natl Acad Sci U S A 96:13409-13414.

Yang S, Qiao H, Wen L, Zhou W, Zhang Y (2005) D-serine enhances impaired long-term potentiation in CA1 subfield of hippocampal slices from aged senescence-accelerated mouse prone/8. Neurosci Lett 379:7-12.

Yang Y, Ge W, Chen Y, Zhang Z, Shen W, Wu C, Poo M, Duan S (2003) Contribution of astrocytes to hippocampal long-term potentiation through release of D-serine. Proc Natl Acad Sci U S A 100:15194-15199.

Zhang JM, Wang HK, Ye CQ, Ge W, Chen Y, Jiang ZL, Wu CP, Poo MM, Duan S (2003) ATP released by astrocytes mediates glutamatergic activity-dependent heterosynaptic suppression. Neuron 40:971-982.

Zhuang ZY, Wen YR, Zhang DR, Borsello T, Bonny C, Strichartz GR, Decosterd I, Ji RR (2006) A peptide c-Jun N-terminal kinase (JNK) inhibitor blocks mechanical allodynia after spinal nerve ligation: respective roles of JNK activation in primary sensory neurons and spinal astrocytes for neuropathic pain development and maintenance. J Neurosci 26:35513560. 